\title{
Analysis of the poverty alleviation status of farmers' cooperatives in Lianghe County, Yunnan Province
}

\author{
Shao-Huimin*1,a , Hou-Liyang ${ }^{* 2, b}$,Su Kaipeng ${ }^{3}$, Wang-Yujiao ${ }^{4}$ \\ ${ }^{1}$ School of Economics and Management Yunnan Normal University, KunMing, China \\ ${ }^{2}$ Yunnan Radio and Television Network Group Kunming Radio and Television Network Co. , Ltd., KunMing, China \\ ${ }^{3}$ School of Economics and Management Yunnan Normal University, KunMing, China \\ ${ }^{4}$ College of Teacher Education, Kunming University, KunMing, China
}

\begin{abstract}
This paper analyzes the poverty alleviation status of cooperatives in Lianghe County, Yunnan Province as an example, first introduces the poverty alleviation situation of Lianghe County, followed by a statistical analysis of the basic situation of farmers' cooperatives in Lianghe County in terms of type of operation, demonstration level, financial support, proportion of poor households, distribution of surplus, etc. The conclusion of the study not only helps Lianghe County to stop the return to poverty, but also helps farmers to cooperate and standardize the development.
\end{abstract}

\section{Introduction}

Lianghe County is located in the northeast of Dehongzhou, Yunnan Province. Lianghe County is under the jurisdiction of 3 towns (Shandao Town, Mandong Town, Yuyuan Town), 6 townships (Pingshan Township, Small Factory Township, Big Factory Township, Jiubao Achang Township, Song Achang Township, Hexi Township); It is also a very typical poverty county in gaohan mountainous area, and it is one of the key border poverty counties in 73 countries in Yunnan Province.

\section{Materials and Methods}

According to the progress of poverty alleviation and development and the characteristics of poverty occurrence in Lianghe County, combined with the potential of industrial development and the operation of cooperative organizations, the managers of the cooperatives of Lianghe County, namely, the town of Shandao, the town of Mandong, the town of Yujiang and Pingshan Township, were selected as the subjects of the study. The study was conducted from June 2018 to March 2019. In this survey, a total of 100 questionnaires were distributed to farmers' cooperative managers and 47 questionnaires were recovered, of which 45 were valid questionnaires. The situation is as shown in Table 1.

Table1. Sample Distribution Table

\begin{tabular}{c|c}
\hline Township & The number of administrators \\
\hline The town of Cover Island & 4 \\
\hline Mandong Town & 28 \\
\hline Raise the town & 1 \\
\hline Pingshan Township & 12 \\
\hline Total & 45 \\
\hline
\end{tabular}

Note: Statistics from survey data.

The survey, a total of 18 cooperatives were visited, of which 10 were plant-based cooperatives, 7 were cultured cooperatives and 1 was integrated cooperatives. The situation is as shown in Table 2 .

\footnotetext{
a* Corresponding author: 562859539@qq.com

b*Corresponding author: 572682733@qq.com
} 
Table2. Types of cooperatives

\begin{tabular}{l|c|l|l|l|l|l|l|l}
\hline \multicolumn{1}{c|}{ Township } & $\begin{array}{l}\text { Number of } \\
\text { cooperatives }\end{array}$ & Food & Fruit & $\begin{array}{l}\text { Fungu } \\
\mathrm{s}\end{array}$ & Tea & Oil & $\begin{array}{l}\text { Breedi } \\
\text { ng }\end{array}$ & Other \\
\hline $\begin{array}{l}\text { The town of Cover } \\
\text { Island }\end{array}$ & 4 & 0 & 0 & 0 & 1 & 0 & 2 & 1 \\
\hline Mandong Town & 7 & 0 & 0 & 2 & 0 & 0 & 4 & 1 \\
\hline Raise the town & 1 & 0 & 0 & 0 & 0 & 0 & 0 & 1 \\
\hline Pingshan Township & 6 & 1 & 0 & 0 & 2 & 4 & 3 & 0 \\
\hline Total & 18 & 1 & 0 & 2 & 3 & 4 & 9 & 3 \\
\hline
\end{tabular}

Note: Statistics from survey data.

\section{Results \& Discussion}

\subsection{Basic situation of farmers' cooperatives}

Of the 18 farmers' cooperatives surveyed, the types of leaders were mostly farmers-owned, reaching 83.33 per cent, followed by leading enterprises (11.11 per cent) and government-led organizations (5.56 per cent). If the cooperative is classified according to whether it is established on the basis of the inner needs of farmers, cooperatives can be divided into endo-type and exo-type cooperatives, i.e., farmer-run types correspond to endotype cooperatives, and others correspond to exocooperatives $^{[1]}$. It follows from this that the proportion of endo-type cooperatives is 83.33 per cent, compared with 16.67 per cent of exoded persons.

From the demonstration level, only Pingshan eco-tea animal demonstration professional cooperatives for the national demonstration cooperatives, accounting for 5.56 per cent, provincial demonstration society, accounting for 5.56 per cent, two municipal demonstration society, accounting for 11.11 per cent, and most cooperatives have no demonstration level, accounting for 77.78 per cent. From a certain point of view, the irregularity of cooperative development is obvious. It may also be seen $\mathrm{f}$ that the higher the level of demonstration of cooperatives in general, the greater the level of financial support or the intensity of financial support obtained ${ }^{[2]}$. However, there is also the phenomenon that cooperatives without demonstration levels can also obtain a certain degree of financial support, and communication with managers has found that most of these subsidies come from industrial policy subsidies. Judging from the surplus distribution of the 18 cooperatives surveyed, only 7 had a surplus distribution of 38.89 per cent, which could further confirm the existence of a large number of irregularly developed cooperatives.

The cooperative with the highest proportion of poor households is the eco-tea professional cooperative in the village of Shuishui, the number of poor members accounted for $42.50 \%$ of the total number of cooperatives, and the lowest was the professional cooperative of Mangang agricultural machinery, which accounted for only 2.13 percent, with an average of 11.72 percent, as detailed in table 3. Analysed from the type of lead, the proportion of poor households in farmers' self-run cooperatives was highest, at 65.78 per cent, followed by government-run (20 per cent) and leading enterprises
(14.22). This result indirectly verifies the author's previous research results, that is, the relationship trust and cooperation are positively related, and the influence of institutional trust on cooperation is not significant, this result is mainly influenced by Chinese culture, the establishment of trust is based on relationship rather than system. Chinese farmers' cooperatives are mostly established on the basis of blood and geographicality, and their growth depends not only on the formal contract between cooperatives and members, but also on the informal contractual relationship between cooperatives and members. From the perspective of cooperative demonstration level, the proportion of poor households in state-level demonstration society, provincial demonstration society and municipal demonstration society is $12.61 \%, 3.48 \%$ and $11.06 \%$, respectively, while the proportion of poor households in cooperatives without demonstration level is as high as $72.85 \%$. This result gives rise to another deep reflection of the author, namely, the willingness of cooperatives to absorb behavioural recognition from poor farmers in the context of cooperative alienation. In a unique case, a similar situation has emerged from the perspective of financial support, i.e. the proportion of poor cooperative households without financial support is as high as 76.32 per cent, while the proportion of poor cooperative households with support at the provincial and ministerial levels, at the municipal level and other sectors supporting cooperatives is 3.3 per cent, 4 per cent and 16.38 per cent, respectively. Analysed by the availability of surplus distributions, the proportion of poor households in unextributed cooperatives was as high as 78.66 per cent, followed by cooperatives with annual closes (10.92 per cent) and closed cooperatives (10.42 per cent).

With regard to the participation of cooperatives in government poverty alleviation projects, 9 out of 18 cooperatives are involved in poverty alleviation projects in government departments, and most of these nine cooperatives are financially supported, but in terms of the type of operation, 8 are run by farmers and the other by leading enterprises. At the same time, three of the nine cooperatives are model cooperatives and two are in surplus distribution. Poverty-stricken members of 10 cooperatives were lifted out of poverty, of which the lowest rate of poverty-relief cooperatives was the Mandong High-Quality Meat and Sheep Farming Cooperative ( 22.22 per cent), which was run by farmers, had no model level, had no financial support, distributed surpluses on a monthly scale and participated in government poverty alleviation projects. The cooperatives 
with the highest rate of poverty alleviation are Xingtai Cattle Professional Cooperative, Mangang Agricultural Machinery Professional Cooperative and Border White Flower Oil Tea Co-operative, all 100 per cent. The similarity of these three cooperatives is that the types of management are farmers themselves, enjoy financial support, and have no surplus distribution. The remaining six cooperatives with members of the Poverty Relief Society are financially supported, most of them farmers themselves.

Table 3 Percentage of poor households

Statistics Unit: \%

\begin{tabular}{l|l|c}
\hline Question item & Sub-items & Average \\
\hline \multirow{4}{*}{ The type of lead } & The farmers run their own & 65.78 \\
\cline { 2 - 3 } & Leading enterprises & 14.22 \\
\cline { 2 - 3 } & The government is in the lead & 20 \\
\hline \multirow{5}{*}{ Femonstration level } & National & 12.61 \\
\cline { 2 - 3 } & Provincial & 3.48 \\
\cline { 2 - 3 } & City level & 11.06 \\
\cline { 2 - 3 } & No & 72.85 \\
\hline \multirow{3}{*}{ Dividend form } & Support at the provincial and & 3.3 \\
\cline { 2 - 3 } & ministerial levels & 4 \\
\cline { 2 - 3 } & Support at the municipal level & 16.38 \\
\cline { 2 - 3 } & Support from other sectors & 76.32 \\
\cline { 2 - 3 } & No & 10.92 \\
\hline & Annual close & 10.42 \\
\cline { 2 - 3 } & The end of the month & 78.66 \\
\cline { 2 - 3 } & No & \\
\hline
\end{tabular}

\subsection{Measures taken by farmers' cooperatives to support poor members}

In setting up the questionnaire, this question is set as a multiple-choice question, regarding the measures of farmers' cooperatives to support poor members, in addition to the six items shown in Figure 1, there is an "other" option, but no one ticked, which can also be inferred that farmers' cooperatives to support poor members measures.The main measures to alleviate poverty for cooperatives through the unified sale of agricultural products account for 21.15 per cent, which also indirectly reflects that the main purpose of poor farmers' choice to join cooperatives is to sell agricultural products, since only farmers who sell their products can obtain economic income. Ten managers chose poor households to work in cooperatives, accounting for 19.23 per cent, followed by organizational training (17.31 per cent), field guidance (13.46 per cent), preferential seeding (11.54 per cent), concessional provision of agricultural capital (7.69 per cent), subsidies for rental cooperative land (5.77 per cent) and micro-credit support (3.85 per cent). See table 4.

Table4 Findings on whether cooperatives can help poor members out of poverty

\begin{tabular}{c|c|c|c|c|c}
\hline $\begin{array}{c}\text { Question } \\
\text { item }\end{array}$ & Yes & $\begin{array}{c}\text { There is a certain role in } \\
\text { promoting }\end{array}$ & $\begin{array}{c}\text { It doesn't work very } \\
\text { well }\end{array}$ & $\begin{array}{c}\text { It basically } \\
\text { doesn't work }\end{array}$ & Total \\
\hline Number & 29 people & 13 people & 3 people & 0 people & 45 people \\
\hline Percentage & $64.44 \%$ & $28.89 \%$ & $6.67 \%$ & $0.00 \%$ & $100 \%$ \\
\hline
\end{tabular}

\subsection{Problems encountered by farmers' cooperatives in the process of poverty alleviation}

In the field research on Lianghe, it was found that the biggest obstacles encountered by farmers' cooperatives in the process of poverty alleviation were weak publicity and promotion, limited sales channels $(27.66 \%)$, followed by insufficient policy support $(25.53 \%)$, poor households' poor people's awareness of poverty alleviation (21.28\%), decentralized operation, difficult to control quality
$(14.89 \%)$ and loose relationship with poor households $(10.64 \%)$.

\subsection{The attitude of managers towards the function of farmers' cooperatives to lift themselves out of poverty}

Seven of the 45 cooperative managers surveyed were Communist Party members of China, and five of the seven were village cadres. According to the results of the survey, the vast majority of managers believe that cooperatives can help poor members out of poverty, accounting for 64.44 percent, and 13 managers believe that cooperatives 
have a certain role in helping poor members out of poverty (28.89 percent), while 3 managers are not very optimistic about the function of cooperatives in poverty reduction, and that cooperatives have little effect on poverty alleviation of poor members.

\section{Conclusions}

The results of the study show that (1) from the 18 cooperative surplus distributions studied, only 7 have carried out surplus distribution, accounting for 38.89 percent, from which it can further confirm the existence of a large number of irregular cooperatives; The highest proportion of poor households in cooperatives of the type was 65.78 per cent, followed by the lower the ratio of government-run (20 per cent) to leading enterprises (14.22);(3) the lower the number of poor farmers absorbed by cooperatives with higher levels of support; The measures taken by farmers' cooperatives to support poor members mainly include the unified sale of agricultural products $(21.15 \%)$, the work of poor households in cooperatives $(19.23 \%)$, and the organization of training (17.31\%);(5) farmers' cooperatives Problems encountered in the process of poverty alleviation from large to small sort of poor publicity and promotion, unlimited sales channels $(27.66 \%)$, followed by insufficient policy support $(25.53 \%)$, poor households out of poverty awareness is not strong $(21.28 \%)$, Decentralized, difficult to control quality $(14.89 \%)$ and loosely linked to poor households (10.64\%);(6) Most managers believe that cooperatives have an anti-poverty function that can help poor members out of poverty $(64.44 \%)$. In the light of the above conclusions, firstly, it is suggested that cooperatives should propose benefit-linking mechanisms[3], standardize cooperative development ${ }^{[4]}$, strictly abide by cooperative laws ${ }^{[5]}$, and distribute surpluses with quality and quantity.

\section{Acknowledgements}

This paper is the result of the stage research on top-notch talents of the 10,000 people program in Yunnan Province. This paper is also the result of the stage research on National Social Science Research on the Blocking Mechanism for Return to Poverty in Southwest Frontier Ethnic Areas Based on Farmers' Cooperatives (Project No. 19 Bush 153).Funded by the local university joint project of Yunnan Science and Technology Department (project number: 202001BA070001-015).

\section{Resources:}

1. Li Ruchun, Chen Shaojun. Study on the mechanism of the role of farmers' cooperatives in precision poverty alleviation Journal of Hehai University (Philosophical and Social Sciences Edition), 2017, 19 (02).

2. $\mathrm{Xu}$ Xuchu. Play the endethive role of farmers' cooperatives in the fight against poverty China Farmers' Cooperative, 2016, (02).
3. Chen Li, Zhong Ling. The possible path for farmers' cooperatives to participate in poverty alleviation is an example of the development of agricultural industries based on small-farmers Rural Economy, 2017, (05).

4. Gui Yu. The construction of the poverty alleviation mechanism of farmers' cooperatives Journal of North China University of Water and Hydropower (Social Sciences Edition), 2017, 33 (01).

5. Zhao Xiaofeng, Yu Chengwei. The construction of the cooperative mechanism of farmers' cooperative and precise poverty alleviation: theoretical logic and practical path Agricultural Economic Issues, 2016, 37 (04). 